fruit rather later in the Globe edition of the "Works" and a "Primer".

In the Herrick, a taste for fine (not necessarily luxurious) book production was already visible, and in the Museum Pollard was already becoming recognized as the Library's expert on typography. In the same year (1893) this side of his activity was given fresh impetus by two events. Robert Proctor joined the Library's staff; in the next ten years Proctor was to put the history of the first fifty years of printing on a new basis, and Pollard learned much from working with his younger colleague, whose work he completed by founding the Museum's great catalogue of incunabula. He became honorary secretary of the newly founded Bibliographical Society, a post he was to hold until 1934, ten years after his retirement from the keepership of printed books in the Museum. For those forty years Pollard directed the Society, and with the help of Proctor, R. B. MeKerrow, Dr. W. W. Greg and other scholars used it to produce a large body of valuable contributions to the bibliography and history of literature, particularly English literature of the fifteenth, sixteenth and seventeenth centuries.

Another special study of his was the English Bible, of which he published a volume of "Records" in 1911, the fruit of the Museum's exhibition at the tercentenary of the Authorized Version. But he is best known, perhaps, by his application of bibliography to the text of Shakespeare. He published his "Shakespeare's Folios and Quartos" so early as 1909 , and followed it up with other publications, culminating in his British Academy Lecture, "The Foundations of Shakespeare's Text", in 1923, suggesting a new and fruitful method, which has been well used by Prof. J. D. Wilson and others.

In 1887 Pollard married Miss Alice England, of Newnham College, who predeceased him. They had two sons, both of whom were killed in the War of 1914-18, and a daughter, who survives him. Those who knew him at the time of his great loss found his noble bearing an inspiration; it deepened the affection and respect in which he had always been regarded in and outside the Museum for his great talents, his industry, his warm heart and his lofty and religious nature.

Arundell Eisdarle.

\section{Prof. A. E. Jolliffe}

Arthur ERnest Jolliffe, who retired from the professorship of mathematics in the University of London (King's College) in 1936, died in Oxford on March 17, 1944. He was educated at Balliol College, Oxford, won the Junior and Senior University Mathematical Scholarships and, shortly after taking his degree, was elected to a fellowship at Corpus Christi College, Oxford, in 1892. After a year at Lampeter as lecturer, he returned to Oxford as mathematical tutor at Corpus, a post which he held until 1920. He was then appointed professor of mathematics at Royal Holloway College, from which he proceeded to the professorship at King's in 1924.

Jolliffe was one of the outstanding mathematical tutors of his time. On his return to Oxford in 1893, he at once devoted himself wholeheartedly and with complete selflessness to the interests of his pupils. Privileged indeed were the Corpus scholars of his early days, for whom his time was measured not in hours but solely by their capacity to profit by his instruction. His solutions of problems in all branches of mathematics and his methods of exposition were brilliant, and bore full evidence of his powers of clear thinking and of his great originality of mind, and gave hope that he would devote some part of his time to research. But his teaching became an all-absorbing interest, with the result that he published relatively little. He was at his best when talking to two or three pupils at a time in Oxford, and was never quite so happy in London, where it fell to his lot to teach large classes of students. He was quite ruthless with the student who was self-satisfied or uninterested, but spared no pains in helping even the unintelligent, provided he showed a genuine desire for information. He was an excellent head of a mathematical department, inspiring his staff with his keenness, for he took it for granted that all were as conscientious and hard-working as himself. As chairman of a board of examiners he was a tower of strength, and his papers always provided a searching test of the ability of the candidates rather than an opportunity to reproduce a complicated piece of reasoning imperfectly understood.

Jolliffe did not enjoy the leisure of retirement for long, for he was soon recalled to Oxford to help in an emergency in the work of Jesus College, and actually continued in that work until shortly before his death.

S. T. Shovelton.

\section{Dr. Alexander G. McAdie}

We regret to announce the death, on November I, 1943, of Dr. Alexander G. McAdie at the age of eighty years. From 1903 until 1913 he was professor of meteorology in the United States Weather Bureau. In 1913 he became Rotch professor and director of the Blue Hill Meteorological Observatory, which post he held until 1931, when he became professor emeritus. In addition to his contributions to the science of meteorology, he was keenly interested in seismology. In spite of the loss by fire of valuable records in the 1906 California earthquake (while Dr. McAdie was working in San Francisco) he prepared, under the auspices of the Smithsonian Institution, a catalogue of earthquakes on the Pacific coast (1897-1906) which has recently been incorporated in a complete catalogue. In the summer of 1906 he called a meeting in San Francisco which led to the formation of the Seismological Society of America. He was its president during 1910-13, and of the Eastern Section during $1929-30$.

WE regret to announce the following deaths :

Mr. J. W. Bullerwell, lecturer in physics from 1902 until 1938 at King's (formerly Armstrong) College, Newcastle upon Tyne, and secretary of the University of Durham Schools Examination Board during 193242 , on March 17, aged seventy.

Dr. Charles B. Davenport, member of the U.S. National Academy of Sciences, the distinguished geneticist who. was associated for many years with the Cold Spring Harbor Station of the Carnegie Institution of Washington, on February 18, aged seventy-seven.

Dr. E. C. S. Dickson, senior lecturer in physics in the University of Manchester, on April 8.

Mr. L. V. Lester-Garland, principal of Victoria College, Jersey, during 1896-1911, author of a "Flora of Jersey", on March 23, aged eighty-three.

Mr. E. C. Stuart Baker, C.I.E., O.B.E., a leading authority on Indian ornithology, on April 16, aged seventy-nine. 